\title{
New Disease on Ornamental Asparagus Caused by Xanthomonas campestris in Florida
}

\author{
D. J. Norman, Assistant Professor, and J. M. F. Yuen, Biological Scientist, University of Florida, IFAS, Central \\ Florida Research and Education Center, 2807 Binion Rd., Apopka, FL 32703; and N. C. Hodge, Senior Biological \\ Scientist, Department of Plant Pathology, University of Florida, Gainesville, FL 32611
}

\begin{abstract}
Norman, D. J., Yuen, J. M. F., and Hodge, N. C. 1997. New disease on ornamental asparagus caused by Xanthomonas campestris in Florida. Plant Dis. 81:847-850.

From dark, water-soaked lesions on stems of asparagus tree fern (Asparagus virgatus) in commercial nurseries in Florida, 33 xanthomonad strains were isolated. Strains formed large, round, butyrus, bright yellow colonies on yeast dextrose calcium carbonate medium, and were gram negative, oxidase negative, catalase positive, motile, strictly aerobic, and did not hydrolyze starch. Strains were further characterized by carbon substrate utilization patterns (Biolog), and by fatty acid methyl esters (FAME) analyses. The metabolic fingerprints of most strains were similar to Xanthomonas campestris pv. vitians, and X. campestris pv. dieffenbachiae from Xanthosoma or Syngonium. Representative strains from A. virgatus were not pathogenic on Dieffenbachia. X. campestris pv. dieffenbachiae strains that did not hydrolyze starch produced scattered lesions on A. virgatus stems. However, starch-hydrolyzing strains of $X$. campestris pv. dieffenbachiae did not produce symptoms when inoculated onto A. virgatus. FAME analysis indicated the strains were $X$. campestris pv. vitians or $X$. campestris pv. translucens; however, low similarity indices $(\bar{x}=0.461)$ indicated that the asparagus strains were not represented in the MIDI library database. FAME analysis profiles were also compared to the University of Florida database, which contains 1,048 X. campestris strains of which 200 are X. campestris pv. dieffenbachiae. Similarity indices were again low with 15 strains matched to $X$. campestris pv. secalis ( $\bar{x}=0.412$ ), seven strains to $X$. fragariae $(\bar{x}=0.224)$, six strains to $X$. campestris pv. translucens $(\bar{x}=0.437)$, and five strains matched $<0.20$ to other pathovars. Five representative strains were tested on six Asparagus species or cultivars: A. virgatus, A. setaceus, A. macowanii, A. densiflorus 'Sprengeri', A. densiflorus 'Myers', and A. officinalis. All five strains were pathogenic on A. virgatus but were less virulent on A. setaceus and A. densiflorus 'Sprengeri'.
\end{abstract}

The delicate, dark-green foliage of asparagus fern has made it one of the most popular cut foliage crops. The ornamental asparagus industry in Florida began in the late 1800 s with the production of Asparagus setaceus (Plumosa fern) (12). Shipments of cut asparagus fern were sent by train to the northeastern United States for use in flower arrangements. By 1956, 2,000 acres of asparagus fern were in production in Florida (20). By that time, primary production had shifted from growing A. setaceus to A. virgatus (tree fern). Currently, over 3,700 acres of asparagus ferns are grown, with 2,000 acres being planted in A. virgatus and the rest with A. setaceus, A. macowanii, and A. densiflorus (21). Asparagus fern grows well in the sandy soil found in Florida. Plants are cultivated

Corresponding author: D. J. Norman

Florida Agricultural Experiment Station Journal Series No. R-05455.

Accepted for publication 29 April 1997.

Publication no. D-1997-0604-04R

(c) 1997 The American Phytopathological Society mainly under natural oak hammocks but also to a limited extent in shadehouses.

Fungal pathogens such as Fusarium and Alternaria are common on commercially produced edible asparagus (A. officinalis L.) $(4,6,19,23)$. No major bacterial diseases have been recorded for edible asparagus or the closely related ornamental asparagus. This is the first report of bacterial disease of ornamental A. virgatus plants. Diseased plants have water-soaked lesions on stems, and the lesions turn dark brown to black with age, making infected fronds unmarketable as a cut foliage green for floral arrangements.

\section{MATERIAL AND METHODS}

Pathogen isolations. In April of 1995, dark green to brown water-soaked lesions were observed on stems of A. virgatus in Volusia County, Florida. Lesions varied in length from a few millimeters to $1 \mathrm{~cm}$. Samples were surface sterilized for $30 \mathrm{~s}$ in $0.25 \%$ sodium hypochlorite solution, ground in $300 \mu \mathrm{l}$ of sterile distilled water, and dilution-streaked onto modified Kelman's (14) triphenyltetrazolium chloride medium (TZC). Plates were incubated at $27 \pm 1^{\circ} \mathrm{C}$ for $48 \mathrm{~h}$. Single colonies were streaked onto TZC media to assure purity Colonies were smooth, round, entire, butyrus, and brick red in color. A total of 33 strains were collected during an 8-month period from Volusia and Putnam counties in Florida. All strains were further characterized on yeast dextrose calcium carbonate medium (YDC) (29) for colony color and morphology and on cellobiose starch (CS) medium for starch hydrolysis (14). Bacteria grown $48 \mathrm{~h}$ on TZC plates were suspended in sterile saline $(\mathrm{NaCl}, 8.5 \mathrm{~g} / \mathrm{L})$ to a concentration of $1 \times 10^{8} \mathrm{CFU} / \mathrm{ml}$ using techniques of Kolmer et al. (7). Growth characteristics were determined on YDC and $\mathrm{CS}$ after incubation at $27 \pm 1^{\circ} \mathrm{C}$ for 4 days. Each strain was also tested for gram reaction, oxidase, catalase, oxidationfermentation of glucose, and motility following protocols of Suslow et al. (24) and MacFaddin (11).

Pathogenicity and host range. All 33 strains isolated were tested for pathogenicity by mist-inoculating onto $A$. virgatus plants. Inoculum was prepared by growing strains for $24 \mathrm{~h}$ at $27 \pm 1^{\circ} \mathrm{C}$ on Bacto nutrient agar amended with $5 \%$ sucrose. Bacterial growth was subsequently suspended in sterile saline, spectrophotometrically adjusted $\left(\mathrm{A}_{600}\right)$ to $1 \times 10^{8} \mathrm{CFU} / \mathrm{ml}$, and suspensions were applied to two plants with hand sprayers until run-off. Inoculated plants were placed in clear polyethylene bags in the glasshouse for $24 \mathrm{~h}$, and then bags were removed. During the following weeks, plants were misted with water every $30 \mathrm{~min}$ for $15 \mathrm{~s}$ during daylight hours. Temperatures and lighting in the glasshouse were maintained between 18.3 and $32^{\circ} \mathrm{C}$ and at $266 \mu \mathrm{mol} \cdot \mathrm{m}^{-2} \cdot \mathrm{s}^{-1}$, respectively. Plants were examined after 2 weeks for symptom development. If symptoms were present, samples were taken and bacteria were reisolated following the previously described protocol. Reisolated bacterial strains were characterized on YDC and CS media and tested for gram, oxidase, and catalase reactions. For host range testing, five strains that had been isolated from three separate farms over a two county area were selected. Two plants of each of the following six Asparagus spp. or cultivars were used following previously mentioned cultural and inoculation techniques: A. virgatus (Asparagus tree 
fern); A. setaceus (Plumosa fern); A. macowanii (Ming fern); A. densiflorus 'Sprengeri' (Sprengeri fern); A. densiflorus 'Myers' (Foxtail fern); and A. officinalis (edible asparagus). The host range experiment was repeated three times.

Utilization of carbon sources and fatty acid profile comparison. The 33 strains were tested for their ability to utilize 95 carbon sources using the Biolog GN System, version 3.5 (Biolog, Hayward, CA). Strains were grown on Difco tryptic soy agar for $48 \mathrm{~h}$ at $27 \pm 1^{\circ} \mathrm{C}$. Bacterial growth was subsequently suspended in sterile saline and spectrophotmetrically adjusted at $\mathrm{A}_{600}$ to $0.190-0.210$ OD. Individual wells of 96-well test plates were filled with 150 $\mu \mathrm{l}$ of the bacterial suspension and plates were incubated at $27 \pm 1^{\circ} \mathrm{C}$. After $48 \mathrm{~h}$, optical densities were recorded and compared to the Biolog database and the percentage of strains utilizing each carbon source was calculated. X. campestris pv. begoniae (strain X1271) was used as a control.

Fatty acid methyl esters (FAME) analyses were also carried out on the 33 bacterial strains using the MIDI Microbial Identification System, software version TSBA 3.90 (Microbial ID, Inc., Newark, DE). Strains were grown for $24 \mathrm{~h}$ at $27 \pm$ $1^{\circ} \mathrm{C}$ on Trypticase soy broth amended with Bacto (Difco) agar (15 g/L). After $24 \mathrm{~h}$ of growth, approximately $40 \mathrm{mg}$ of bacterial cells (wet weight) were placed in $13 \times 100$ $\mathrm{mm}$ glass tubes fitted with Teflon-lined screw caps. Cellular fatty acids were extracted and derivatized to their FAMEs using procedures described by Miller (13); FAME profiles were statistically compared to the MIDI TSBA 3.90 library $(17,18)$. Three controls were utilized in each fatty acid extraction: 1) reagent control; 2) Stenotrophomonas maltophilia (strain $\mathrm{X} 1128$, used because of multiple peaks as an evaluation of the extraction process); and 3) X. campestris pv. begoniae (strain $\mathrm{X} 1271$ used as a check to confirm specificity of analysis to pathovar level). To further compare FAME profiles, data were compared to the University of Florida's database (ver. 3.90), which contains 1,048 $X$. campestris strains of various pathovars.

Pathogenicity on Dieffenbachia. Using the Biolog assay, $85 \%$ of the 33 strains tested had high similarity values ( $\bar{x}$ similarity index [s.i.] $>0.7$ ) to $X$. campestris pv. dieffenbachiae. To determine if strains isolated from $A$. virgatus are $X$. campestris pv. dieffenbachiae, a substantially different variant of $X$. campestris pv. dieffenbachiae, or a new pathovar, the five prementioned strains along with six $X$. campestris pv. dieffenbachiae strains were tested for pathogenicity on D. maculata 'Camille' and A. virgatus plants. Strains of $X$. campestris pv. dieffenbachiae were selected from the two biotypes present in the population, those that can hydrolyze starch (strains X175, X186, and X195) and those that cannot (strains X454, X758, and X868). Strains X454 and X758 were isolated from Anthurium andraeanum in Hawaii and Florida, respectively, while the other four strains were isolated from Dieffenbachia in Florida. These bacterial strains were cultured, inoculated by mist inoculation onto two plants of each species and reisolations were done after 4 weeks as previously described and experiment was repeated at least once.

To further determine if xanthomonads isolated from $A$. virgatus might be capable of causing infections on Dieffenbachia, the five strains from $A$. virgatus and the six $X$. campestris pv. dieffenbachiae strains were grown, adjusted spectrophotometrically in saline to $1 \times 10^{4} \mathrm{CFU} / \mathrm{ml}$, and injected (5 $\mathrm{cm}^{2}$ infiltration zones) with a 25-gauge hypodermic needle into two leaves of a $D$. maculata 'Camille' plant. Two controls were utilized-sterile saline and Erwinia herbicola (strain E101). Symptom development was monitored over a 4 -week period.

\section{RESULTS}

Pathogen isolations. All strains of Xanthomonas isolated from asparagus fern grew readily on YDC medium and formed large round, butyrus, bright yellow colonies within $48 \mathrm{~h}$. However, growth on CS medium was slow and colonies developed only after 4 days. No starch hydrolysis zones were evident around colonies of any of the strains tested. Additionally, all strains tested in this study were gram negative, oxidase negative, catalase positive, motile, and strictly aerobic.

Pathogenicity and host range. All 33 strains were pathogenic on A. virgatus, forming light green water-soaked lesions on stems within 2 weeks. Over the next 2 weeks, margins of these lesions turned brown and eventually lesions became completely necrotic. Number and size of lesions varied greatly among plants; some formed large discrete water-soaked lesions approximately $1 \mathrm{~cm}$ in length, while others formed hundreds of small lesions $<0.3 \mathrm{~cm}$. The five strains utilized in the host range testing produced lesions on A. virgatus and additionally formed scattered lesions on new growth of $A$. macowanii and A. densiflorus 'Sprengeri' (Fig. 1). However, extent and severity of symptoms varied with indi-
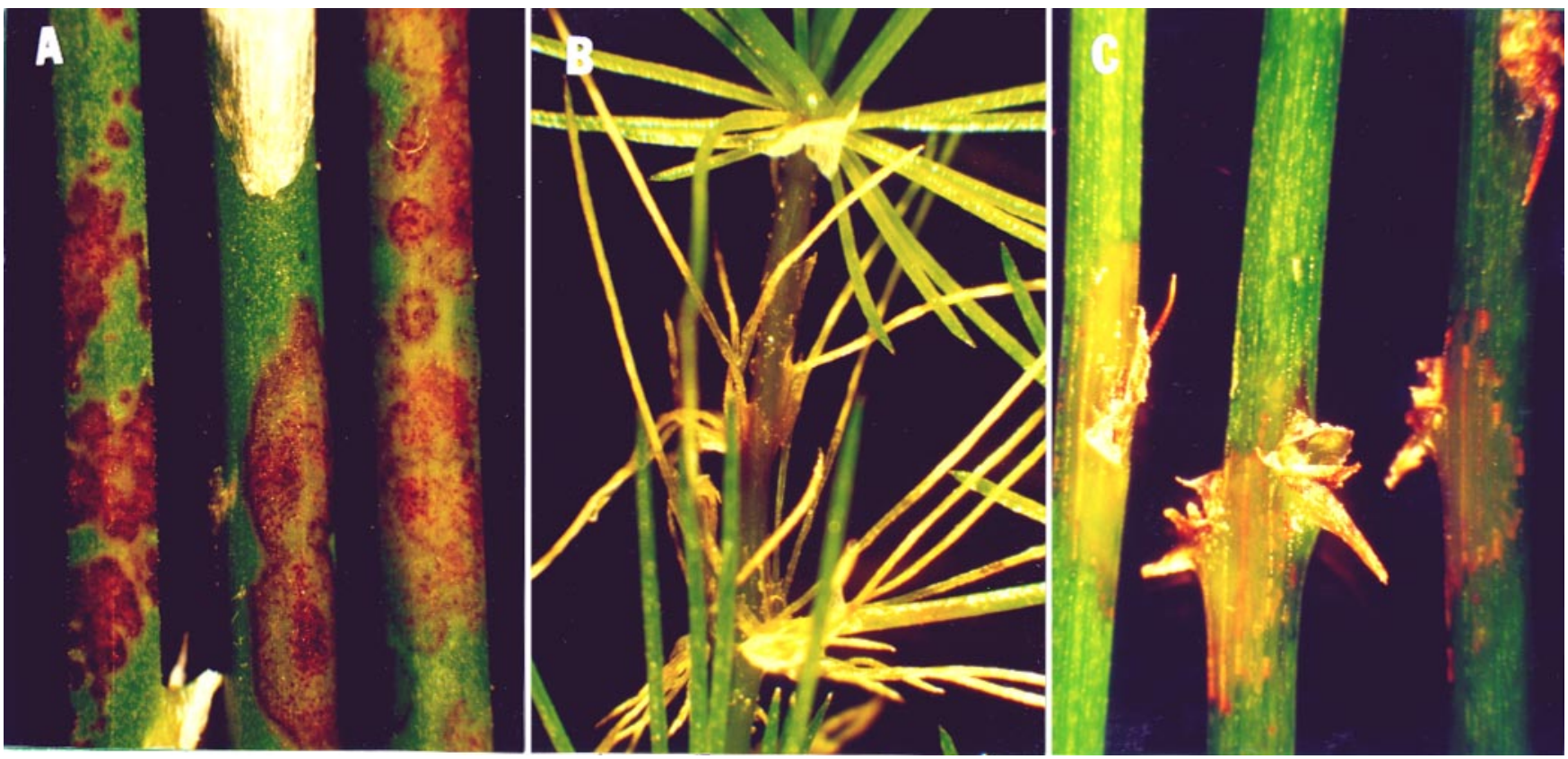

Fig. 1. Symptoms caused by Xanthomonas campestris sp. on stems of (A) Asparagus virgatus (asparagus tree fern) and similar symptoms produced when inoculated onto (B) A. macowanii (plumosa fern) and (C) A. densiflorus (sprengeri fern). 
vidual strains tested (Table 1). Xanthomonas was reisolated and identified using previously outlined techniques from all plants exhibiting lesion development.

Utilization of carbon sources and fatty acid profile comparison. Using the 95 carbon source Biolog System and accompanying software (ver. 3.5), the 33 strains were grouped into four classification groups based on their metabolic fingerprints: 1) $X$. campestris pv. vitians (4 strains, s.i. $\bar{x}=0.604)$; 2) $X$. campestris pv. dieffenbachiae from Xanthosoma (21 strains, $\bar{x}$ s.i.= 0.777); 3) X. c. pv. dieffenbachiae from Syngonium (7 strains, $\bar{x}$ s.i.= 0.750); and 4) X. oryzae (1 strain, s.i. $=0.447)$. Similarity indexes $\geq 0.50$ are considered matches with 1.0 considered a perfect match. Percentages of the 33 strains utilizing each carbon source can be seen in Figure 2. The $X$. campestris pv. begonia strain utilized as a control was identified as $X$. campestris. However, no match was made to a specific pathovar.

FAME analysis using the MIDI data base divided the 33 strains into five groups as follows: 1) X. campestris pv. vitians (13 strains, $\bar{X}$ s.i. $=0.469)$; 2) $X$. campestris pv. translucens (11 strains, $\bar{x}$ s.i. $=0.529)$; 3) $X$. campestris pv. begoniae (7 strains, $\bar{x}$ s.i.= 0.388); 4) X. campestris pv. pelargonii (1 strain, s.i. $=0.206$ ); and 5) $X$. campestris pv. phaseoli (1 strain, s.i. = 0.397). Using the Biolog and FAME analysis techniques, only two strains were classified by both systems as $X$. campestris pv. vitians. The two control strains, $X$. campestris pv. begoniae (strain X1271, s.i. = 0.859 ) and Stenotrophomonas maltophilia $(\mathrm{X} 1128$, s.i. $=0.903)$, were identified to the pathovar and species level, respectively. Using the University of Florida's FAME database, similarity indices were again low with 15 strains being matched to $X$. campestris pv. secalis ( $\bar{x}=0.412), 7$ strains to $X$. fragariae $(\bar{x}=0.224)$, and 6 strains to $X$. campestris pv. translucens $(\bar{x}=0.437)$, with the other 5 strains having matches < 0.20 to other pathovars. Percentages of the five most prevalent fatty acids found in the FAME profiles of the $33 X$. campestris strains isolated from $A$. virgatus are shown in Table 2.

Pathogenicity on Dieffenbachia. All five xanthomonads from A. virgatus formed lesions within 2 weeks on A. vir-

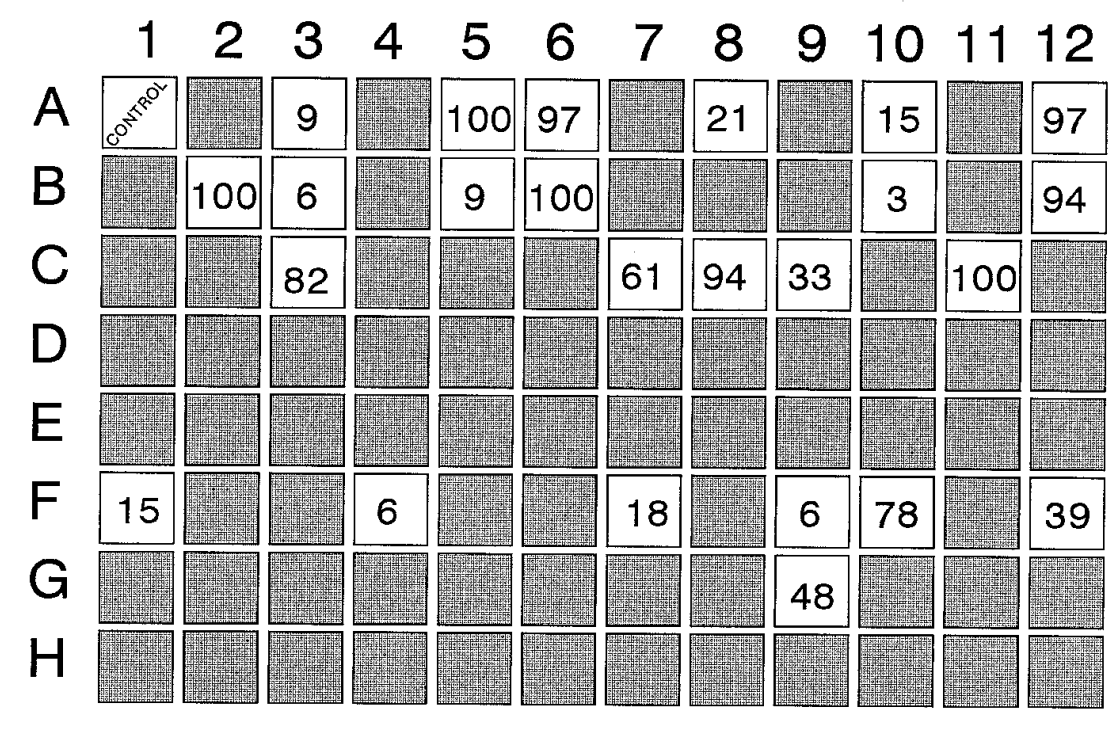

Fig. 2. Percentages of the 33 xanthomonad strains utilizing each carbon compound, using the 95 carbon compound GN Biolog assay. Carbon compounds are defined by letters (rows) and numbers (columns) as follows: A2, $\alpha$-cyclodextrin; A3, dextrin; A4, glycogen; A5, Tween 40; A6, Tween 80; A7, $N$-acetyl-D-galactosamine; A8, $N$-acetyl-D-glucosamine; A9, adonitol; A10, L-arabinose; A11, Darabitol; A12, cellobiose; B1, meso-erythritol; B2, D-fructose; B3, L-fucose; B4, D-galactose; B5, gentiobiose; B6, $\alpha$-D-glucose; B7, meso-inositol; B8, $\alpha$-D-lactose; B9, lactulose; B10, maltose; B11, D-mannitol; B12, D-mannose; C1, D-melibiose; C2, $\beta$-methyl-D-glucoside; C3, D-psicose; C4, Draffinose; C5, L-rhamnose; C6, D-sorbitol; C7, sucrose; C8, D-trehalose; C9, turanose; C10, xylitol; C11, methylpyruvate; C12, mono-methylsuccinate; D1, acetic acid; D2, cis-aconitic acid; D3, citric acid; D4, formic acid; D5, D-galactonic acid lactone; D6, D-galacturonic acid; D7, D-gluconic acid; D8, D-glucosaminic acid; D9, D-glucuronic acid; D10, $\alpha$-hydroxybutyric acid; D11, $\beta$ hydroxybutyric acid; D12, $\gamma$-hydroxybutyric acid; E1, $p$-hydroxyphenylacetic acid; E2, Itaconic acid; E3, $\alpha$-ketobutyric acid; E4, $\alpha$-ketoglutaric acid; E5, $\alpha$-ketovaleric acid; E6, DL-lactic acid; E7, malonic acid; E8, propionic acid; E9, quinic acid; E10, D-saccharic acid; E11, sebacic acid; E12, succinic acid; F1, bromosuccinic acid; F2, succinamic acid; F3, glucuronamide; F4, alaninamide; F5, Dalanine; F6, L-alanine; F7, L-alanylglycine; F8, L-asparagine; F9, L-aspartic acid; F10, L-glutamic acid; F11, glycyl-L-aspartic acid; F12, glycyl-L-glutamic acid; Gl, L-histidine; G2, hydroxy-Lproline; G3, L-leucine; G4, L-ornithine; G5, L-phenylalanine; G6, L-proline; G7, L-pyroglutamic acid; G8, D-serine; G9, L-serine; G10 L-threonine; G 11, DL-carnitine; G12, $\gamma$-aminobutyric acid; H1, urocanic acid; $\mathrm{H}$ 2, inosine; $\mathrm{H} 3$; uridine; $\mathrm{H} 4$, thymidine; $\mathrm{H} 5$, phenyl ethylamine; $\mathrm{H} 6$, putrescine; $\mathrm{H} 7$, 2-aminoethanol; H8, 2,3-butanediol; H9, glycerol; H10, DL $\alpha$-glycerolphosphate; H11, glucose 1phosphate; H12, glucose 6-phosphate. gatus plants. However, no symptoms were observed on Dieffenbachia plants over a 4week period. The three $X$. campestris pv. dieffenbachia strains that were starch hydrolysis negative formed scattered dark brown necrotic lesions on A. virgatus stems within 2 weeks. No symptoms were produced on $A$. virgatus plants by the $X$. campestris pv. dieffenbachia strains that were capable of utilizing starch. All six $X$. campestris pv. dieffenbachia strains were pathogenic on Dieffenbachia forming water-soaked lesions on leaves within 4 weeks. Xanthomonas strains were reisolated from lesions of test plants.

Leaves of all dieffenbachia infiltrated with $X$. campestris pv. dieffenbachiae strains became water-soaked within four days, necrotic within 2 weeks and disease

Table 1. Host range of five xanthomonad strains isolated from Asparagus virgatus, on five of the most commonly cultivated Asparagus species ${ }^{\mathrm{a}}$

\begin{tabular}{lcc}
\hline $\begin{array}{l}\text { Genus/ } \\
\text { Species }\end{array}$ & $\begin{array}{c}\text { Common } \\
\text { Name }\end{array}$ & Symptoms \\
\hline $\begin{array}{l}\text { Asparagus } \\
\text { virgatus }\end{array}$ & Tree fern & $+^{\mathrm{c}}$ \\
$\begin{array}{l}\text { A. setaceus } \\
\text { A. macowanii }\end{array}$ & $\begin{array}{c}\text { Plumosa fern } \\
\text { Ming fern }\end{array}$ & $+/$ - $^{\mathrm{d}}$ \\
$\begin{array}{l}\text { A. densiflorus } \\
\text { 'Sprengeri' }\end{array}$ & $\begin{array}{c}\text { Sprengeri fern } \\
+/-\mathrm{f}\end{array}$ \\
$\begin{array}{l}\text { A. densiflorus } \\
\text { 'Myers' }\end{array}$ & Foxtail fern & - \\
A. officinalis & Edible & - \\
Control (saline) & asparagus & \\
\hline
\end{tabular}

a Experiment repeated three times with two replicate plants of each cultivar.

b A suspension containing Xanthomonas at $1 \times$ $10^{8} \mathrm{CFU} / \mathrm{ml}$ was misted onto surface of plants.

c Water-soaked lesions on stem of asparagus plants.

d Two of the five strains produced a few (1 to 4), scattered, water-soaked lesions.

e No symptoms observed four weeks after inoculation.

${ }^{\mathrm{f}}$ All five strains produced lesions but only on half of the plants.

g Jersey Knight Hybrid, Park Seed, Greenwood, SC.

Table 2. Percentages of five fatty acids ${ }^{\mathrm{a}}$ in the FAME profile of 33 Xanthomonas campestris strains isolated from Asparagus virgatus

\begin{tabular}{lrrcc}
\hline Fatty Acid & Mean & SD $^{\mathbf{b}}$ & Std/Mean \\
\hline 11:0 ISO & 5.63 & 0.41 & 0.07 \\
14:0 & 2.01 & 0.14 & 0.07 \\
15:0 ISO & 28.29 & 2.62 & 0.09 \\
15:0 anteiso $^{c}$ & 7.26 & 1.22 & 0.17 \\
NRD $^{\text {d }}$ & 24.97 & 2.04 & 0.08 \\
\hline
\end{tabular}

a These five fatty acids comprised approximately $68 \%$ of the total profile of the strains tested.

b Standard deviation.

c A structural isomer of 15:0 ISO, note higher variability in production relative to mean.

$\mathrm{d}$ NRD $=$ not reliably differentiated by MIDI includes 16:1 $\omega 7 \mathrm{cis}$ and 15:0 iso $2 \mathrm{OH}$. 
spread within the plant became evident by week four. However, no symptoms were observed on Dieffenbachia plants in which xanthomonad strains from $A$. virgatus, saline, or E. herbicola controls had been infiltrated.

\section{DISCUSSION}

Host range studies on asparagus species and on dieffenbachia indicate that the xanthomonads isolated from A. virgatus have a very limited host range. Only $A$. virgatus was infected, and scattered lesions were also produced on stems of A. macowanii and $A$. densiflorus 'Sprengeri'. In the field, diseased $A$. virgatus plantings within a few feet of plantings of $A$. macowanii or A. densiflorus 'Sprengeri' produced no infections on these species. In infested production fields, outbreaks were always observed in A. virgatus plantings, which either had a very thick growth of asparagus ferns or an abundance of weeds. This suggests that the high humidity produced in the thick growth of plants may be necessary for infection. Weeds in infested fields were not infected by xanthomonads. In laboratory inoculations, infection occurred only on young asparagus stems that were still growing, never on old hardened-off fronds. New infections in production fields were observed in the spring and in the fall. This may be related to flushes of new growth or to more moderate temperatures.

It is difficult to discriminate among $X$. campestris pathovars without extensive pathogenicity testing. However, different techniques have been successfully employed such as monoclonal antibodies $(1,9)$, SDS polyacrylamide gel electrophoresis $(26,27)$, DNA hybridization $(5,25)$, restriction fragment-length polymorphism (8), and genomic DNA fingerprinting $(3,10,15)$. However, widespread use of some of these methods is limited due to expense, time, spectrum of use, or ability to differentiate strains at the pathovar level. Both FAME analysis and metabolic fingerprints (Biolog) have been successfully used to distinguish pathovars of $X$. campestris $(2,16,22,27,28)$. Controls utilized in the FAME analysis had high similarity values with existing databases. However, low similarity values were obtained for the 33 strains tested from asparagus. These low values were not produced in a single FAME extraction but were consistent even when new extractions were made. The low values obtained when using either the MIDI or University of Florida database indicate that these xanthomonad strains are probably a distinct $X$. campestris pathovar or a unique variant that is metabolically similar to $X$. campestris pv. dieffenbachiae strains that do not hydrolyze starch. $X$. campestris pv. dieffenbachiae strains isolated from Syngonium and Xanthosoma are usually unable to hydrolyze starch, which may substantiate relatedness of these strains to those from asparagus. It appears from this study that the $X$. campestris strains from asparagus may in fact be a variant of $X$. campestris pv. dieffenbachiae and that the ability to hydrolyze starch may be directly related to host range of members of this very heterogeneous pathovar. To answer these questions, additional research involving genetic comparisons and extensive host range testing would be needed.

The xanthomonads infecting A. virgatus plantings are currently found only on a few farms in two counties in Florida but have the potential, under appropriate environmental conditions, to become a major pathogen of $A$. virgatus plantings.

\section{LITERATURE CITED}

1. Alvarez, A. M., Benedict, A. A., and Mizumoto, C. Y. 1985. Identification of xanthomonads and grouping of Xanthomonas campestris with monoclonal antibodies. Phytopathology 75:722-728.

2. Chase, A. R., Stall, R. E., Hodge, N. C., and Jones, J. B. 1992. Characterization of Xanthomonas campestris strains from aroids using physiological, pathological and fatty acid analyses. Phytopathology 82:754-759.

3. Cooksey, D. A., and Graham, J. H. 1989. Genomic fingerprinting of two pathovars of phytopathogenic bacteria by rare-cutting restriction enzymes and field inversion gel electrophoresis. Phytopathology 79:745750 .

4. Elmer, W. H., Johnson, D. A., and Mink, G. I. 1996. Epidemiology and management of the diseases causal to asparagus decline. Plant Dis. 80:117-125.

5. Hildebrand, D. C., Palleroni, N. J., and Schroth, M. N. 1990. Deoxyribonucleic acid relatedness of 24 xanthomonad strains representing 23 Xanthomonas campestris pathovars and Xanthomonas fragariae. J. Appl. Bacteriol. 68:263-269.

6. Johnston, S. A., Springer, J. K., and Lewis, G. D. 1979. Fusarium moniliforme as a cause of stem and crown rot of asparagus and its association with asparagus decline. Phytopathology 69:778-780.

7. Kolmer, J. A., Spaulding, E. H., and Robison, H. W. 1959. Approved Laboratory Technic. Appleton-Century-Crofts, New York, pp. 582583.

8. Lazo, G. R., Roffey, R., and Gabriel, D. W. 1987. Pathovars of Xanthomonas campestris are distinguishable by restriction fragmentlength polymorphism. Int. J. Syst. Bacteriol. 37:214-221.

9. Lipp, R. L., Alvarez, A. M., and Benedict, A. A. 1992. Use of monoclonal antibodies and pathogenicity tests to characterize strains of Xanthomonas campestris pv. dieffenbachiae from aroids. Phytopathology 82:677-682.

10. Louws, F. J., Fulbright, D. W., Stephens, C. T., and de Bruijn, F. J. 1995. Differentiation of genomic structure by rep-PCR fingerprinting to rapidly classify Xanthomonas campestris pv. vesicatoria. Phytopathology 85:528536.

11. MacFaddin, J. F. 1981. Biochemical Tests for Identification of Medical Bacteria, 2nd ed. Williams and Wilkins, London, pp. 527.

12. Manning, R. D. 1984. From orange to green "gold": The roots of the asparagus fern industry in Florida. Fla. Hist. Quart. 62:464484.
13. Miller, L. T. 1982. Single derivation method for routine analysis of bacterial whole-cell fatty acid methyl esters, including hydroxy acids. J. Clin. Microbiol. 16:584-586.

14. Norman, D., and Alvarez, A. 1989. A rapid method for the presumptive identification of Xanthomonas campestris pv. dieffenbachiae and other xanthomonads. Plant Dis. 73:654658.

15. Pruvost, O., Hartung, J. S., Civerolo, E. L., Dubois, C., and Perrier, X. 1992. Plasmid DNA fingerprints distinguish pathotypes of Xanthomonas campestris pv. citri, the causal agent of citrus bacterial canker disease. Phytopathology 82:485-490.

16. Roy, M. A. 1988. Use of fatty acids for the identification of phytopathogenic bacteria. Plant Dis. 72:460.

17. Sasser, M. 1990. Identification of bacteria through fatty acid analysis, Pages 199-204 in: Methods in Phytobacteriology. Z. Klement, K. Rudolph, and D. Sands, eds.,. Akademiai Kiado, Budapest.

18. Sasser, M. J. 1990. Technical note \#101: Identification of bacteria by gas chromatography of cellular fatty acids. MIDI, Newark, DE.

19. Schreuder, W., Lamprecht, S. C., Marasas, W. F. O., and Calitz, F. J. 1995. Pathogenicity of three Fusarium species associated with asparagus decline in South Africa. Plant Dis. 79:177-181.

20. Stamps, R. H. 1989. Florida's cut foliage industry - from plumosa to leatherleaf fern, Part 1 - Production. Cut Foliage Grower 4 (3/4): $1-5$.

21. Stamps, R. H. 1994. Florida cut foliage shipments drop by $2 \%$ but sales continue to increase. Cut Foliage Grower 9 (3/4):1-4.

22. Stead, D. E. 1989. Grouping of Xanthomonas campestris pathovars of cereals and grasses by fatty acid profiling. OEPP/EPPO bulletin 19:57-69.

23. Stephens, C. T., and Elmer, W. H. 1988. An in vitro assay to evaluate sources of resistance in Asparagus spp. to Fusarium crown and root rot. Plant Dis. 72:334-337.

24. Suslow, T. V., Schroth, M. N., and Isaka, M. 1982. Application of a rapid method for gram-differentiation of plant pathogenic and saprophytic bacteria without staining. Phytopathology 72:917-918.

25. Vauterin, L., Vantomme, R., Pot, B., Hoste, B., Swings, J., and Kersters, K. 1990. Taxonomic analysis of Xanthomonas campestris pv. begoniae and $X$. campestris pv. pelargoni by means of phytopathological, phenotypic, protein electrophoretic and DNA hybridization methods. Syst. Appl. Microbiol. 13:166 176.

26. Vauterin, L., Yang, P., Hoste, B., Vancanneyt, M., Civerolo, E. L., Swings, J., and Kersters, K. 1991. Differentiation of Xanthomonas campestris pv. citri strains by sodium dodecyl sulfate-polyacrylamide gel electrophoresis of proteins, fatty acid analysis, and DNA-DNA hybridization. Int. J. Syst. Bacteriol. 41:535542.

27. Vauterin, L., Yang, P., Hoste, B., Pot, B., Swings, J., and Kersters, K. 1992. Taxonomy of xanthomonads from cereals and grasses based on SDS-PAGE of proteins, fatty acid analysis, and DNA hybridization. J. Gen. Microbiol. 138:1467-1477.

28. Vauterin, P., Hoste, B., Kersters, K., and Swings, J. 1995. Reclassification of Xanthomonas. Int. J. Syst. Bacteriol. 45:472-489.

29. Wilson, E. E., Zeitoun, F. M., and Fredrickson, D. L. 1967. Bacterial phloem canker, a new disease of Persian walnut trees. Phytopathology 57:618-621. 